American Journal of Applied Sciences 7 (7): 914-921, 2010

ISSN 1546-9239

(C) 2010 Science Publications

\title{
Factors Affecting the Synthesis and Formation of Single-Phase Barium Hexaferrite by a Technique of Oxalate Precursor
}

\author{
Q. Mohsen \\ Materials and Corrosion Lab (MCL), Faculty of Science, Taif University, Saudi Arabia
}

\begin{abstract}
Problem statement: Barium hexaferrite $\left(\mathrm{BaFe}_{12} \mathrm{O}_{19}\right)$, is of great importance as permanent magnets, particularly for magnetic recording as well as in microwave devices. Approach: The aim of this study was to synthesize Stoichiometric and single-phase barium hexaferrite through a technique of oxalate precursor. Effects of different $\mathrm{Fe}^{3+} / \mathrm{Ba}^{2+}$ mole ratio and annealing temperature on the particle size, microstructure and magnetic properties of the resulting barium hexaferrite powders has been studied and reported in the presented research. The annealing temperature was controlled from 900$1200^{\circ} \mathrm{C}$, while the $\mathrm{Fe}^{3+} / \mathrm{Ba}^{2+}$ was controlled from 12-8.57. Results: The resultant powders were investigated by Differential Thermal Analyzer (DTA), X-Ray Diffractometer (XRD), Scanning Electron Microscopy (SEM) and Vibrating Sample Magnetometer (VSM). Single phase of well crystalline $\mathrm{BaFe}_{12} \mathrm{O}_{19}$ was first obtained at $\mathrm{Fe}^{3+} / \mathrm{Ba}^{2+}$ mole ratio of 9.23 and 8.57 at annealing temperature $1100^{\circ} \mathrm{C}$. Moreover, at annealing temperature $1200^{\circ} \mathrm{C}$ the single phase $\mathrm{BaFe}_{12} \mathrm{O}_{19}$ appeared at all different $\mathrm{Fe}^{3+} / \mathrm{Ba}^{2+}$ mole ratio. The SEM results showed that the grains were regular hexagonal platelets. In addition, maximum saturation magnetization $\left(70.25 \mathrm{emu}^{-1}\right)$ was observed at mole ratio 10 and annealing temperature $1200^{\circ} \mathrm{C}$. However, it was found that the coercivety of the synthesized $\mathrm{BaFe}_{12} \mathrm{O}_{19}$ samples were lower than the theoretical values. Conclusion: The barium hexaferrite was synthesized at annealing temperature $1200^{\circ} \mathrm{C}$ with a single phase using oxalate as precursor route.
\end{abstract}

Key words: Barium hexaferrite, annealing temperature, mole ratio, magnetic properties, oxalate precursor

\section{INTRODUCTION}

Permanent magnet materials are essential in devices for storing energy in a static magnetic field. Ferrite is a class of ceramic materials with useful electromagnetic properties and the electromagnetic properties for ferrite materials is affected by operating conditions such as temperature, pressure, field strength, frequency and time. Ferrites play an important role in the field of electronics industry because they are relatively inexpensive, more stable and easily manufactured. Ferrites are widely used in microwave devices, permanent magnets, high density magnetic and magneto-optic recording media and telecommunications devices. Hexagonal ferrites, $\mathrm{MFe}_{12} \mathrm{O}_{19}$, (where $\mathrm{M}=\mathrm{Ba}, \mathrm{Sr}$ and/or $\mathrm{Pb}$ ) are a group of magnetic compounds, which all have high resistivity, magneto-crystalline anisotropy and saturation magnetization, low dielectric losses and are thermally stable well above their Curie temperature (Kojimi and Wohlfarth, 1982; Smit and Wijn, 1959). The hexagonal M-type hard ferrites have attracted much attention as the most widely used permanent magnets, which account for about $90 \%$ of the annual production of the permanent magnets due to the good combination of high magnetic properties, chemical stability and low cost. Moreover, M-type hexaferrites have widely used in telecommunication, magnetic recording media, magneto-optics and microwave devices (Kojima, 1982; Smit and Wijn, 1959; Ogasawara and Oliveira, 2000). As a result of its specific magnetic properties, barium hexaferrite and its derivatives can be used for permanent magnets, magnetic recording media and microwave applications (Hessien et al., 2008). $\mathrm{BaFe}_{12} \mathrm{O}_{19}(\mathrm{BaM})$ and its derivatives are currently magnetic material with great scientific and technological interest, due to its relatively high curie temperature, high coercive force and high magnetic anisotropy field as well as an excellent chemical stability and corrosion resistivity (Kojimi and Wohlfarth, 1982). Barium hexaferrite $\left(\mathrm{BaFe}_{12} \mathrm{O}_{19}\right)$ has a complex hexagonal unit cell and belonging to the magnetoplumbite structures (Richerson, 1992). Magnetoplumbite are of the type $\mathrm{A}^{2+} \mathrm{O} 1.6 \mathrm{~B}_{2}{ }^{3+} \mathrm{O}_{3}$. The arrangement of the $12 \mathrm{Fe}^{3+}$ ions in the unit cell is as follows: Two ions in the tetrahedral sites (four nearest $\mathrm{O}^{2-}$ neighbors), nine ions in the octahedral sites (six nearest $\mathrm{O}^{2-}$ neighbors) and one ion in the hexagonal site 
(five nearest $\mathrm{O}^{2-}$ neighbors). Materials of this type have a strong uniaxial magnetic direction, making as permanent magnets. The reported theoretical calculated coercive force, saturation magnetization and curie temperature values for pure and single domain barium hexaferrite was $6700 \mathrm{Oe}, 72 \mathrm{emu} \mathrm{g}^{-1}$ and $450^{\circ} \mathrm{C}$, respectively (Miller and Drillon, 2002; Pillai et al., 1993). It is difficult to obtain ultrafine and monodispersed particles by the conmmercial ceramic method (solid-state reaction) which involves the firing of stoichiometric mixture of barium carbonate and iron oxide at high temperatures (about $1200^{\circ} \mathrm{C}$ ) (Cabaoas and Gonzalez-Calbet, 1993). In this respect, several low-temperatures chemical methods were investigated for the formation of ultrafine $\mathrm{BaFe}_{12} \mathrm{O}_{19}$ particles. These methods comprised coprecipitation (Hessien et al., 2008; Jacobo et al., 1997; Matutes-Aquino et al., 2000), hydrothermal (Wang et al., 1993; Liu et al., 1999; Mishra et al., 2004), sol-gel (Surig et al., 1996; Zhong et al., 1997; Garcia et al., 2001; Jacobo et al., 1997), microemulsion (Pillai et al., 1993), oxalate precursor (Sankaranarayanan and Khan, 1996), glass crystallization (El-Hilo et al., 1994), sonochemical (Shafi and Gedanken, 1999) and mechano-chemical activation (Abe and Narita, 1997). The oxalate precursor technique was found to be more suitable for synthesis of barium ferrite with single phase powder. In addition, this technique needs relatively low-processing temperature to produce homogenous microstructure with narrow size distribution and uniform shape. In this study, the oxalate precursor technique was used to synthesize nanocrystalline barium ferrite with high saturation magnetization. Effects of $\mathrm{Fe}^{3+} / \mathrm{Ba}^{2+}$ mole ratios and the annealing temperature on the synthesis of ferrite powders were investigated. The annealing temperature was controlled from $900-1200^{\circ} \mathrm{C}$, while $\mathrm{Fe}^{3+} / \mathrm{Ba}^{2+}$ mole ratios were controlled from 12-8.57.

\section{MATERIALS AND METHODS}

Preparation: The oxalate precursor method was applied for the preparation of Barium hexaferrite $\left(\mathrm{BaFe}_{12} \mathrm{O}_{19}\right)$. Chemically grade ferric chloride $\left(\mathrm{FeCl}_{3}\right.$ $\left.6 \mathrm{H}_{2} \mathrm{O}\right)$, barium chloride $\left(\mathrm{BaCl}_{2} \cdot \mathrm{H}_{2} \mathrm{O}\right)$ and oxalic acid as source of organic were used as starting materials. A series of ferric chloride and barium chloride solution with various $\mathrm{Fe}^{3+} / \mathrm{Ba}^{2+}$ molar ratios of $(12,10.9,10$, 9.23 and 8.57) and containing equivalent amount of oxalic acid were prepared. The mixtures of barium chloride and ferric chloride solution firstly prepared and then stirred for 15 min on a hot-plate magnetic stirrer, followed by addition of an aqueous solution, which was evaporated to $80^{\circ} \mathrm{C}$ with constant stirring until dry and then dried in a dryer at $100^{\circ} \mathrm{C}$ overnight. The dried powders obtained as barium ferrite precursors.
Measurements: Differential Thermal Analyzer (DTA) analysis of various un-annealed precursors was carried out. The rate of heating was kept at $10^{\circ} \mathrm{C} \mathrm{min}^{-1}$ between room temperature and $1000^{\circ} \mathrm{C}$. The measurements were carried out in a current of argon atmosphere.

For the formation of the barium ferrite phase, the dry precursors were annealed at the rate of $10^{\circ} \mathrm{C} \mathrm{min}^{-1}$ in static air atmosphere up to different temperatures (900-1200 ${ }^{\circ} \mathrm{C}$ and maintained at the temperature for annealed time $(2 \mathrm{~h})$. The crystalline phases presented in the different annealed samples were identified by XRD on a Brucker axis D8 diffractometer using $\mathrm{Cu}$ $\mathrm{K} \alpha \quad(\lambda=1.5406)$ radiation and secondary monochromator in the range $2 \varnothing$ from $10-80^{\circ}$. The ferrites particles morphologies were observed by Scanning Electron Microscope (SEM, JSM-5400).

The magnetic properties of the ferrites were measured at room temperature using a Vibrating Sample Magnetometer (VSM; 9600-1 LDJ, USA) in a maximum applied field of $10 \mathrm{kOe}$. From the obtained hysteresis loops, the saturation Magnetization $\left(\mathrm{M}_{\mathrm{s}}\right)$, remanence Magnetization $\left(\mathrm{M}_{\mathrm{r}}\right)$ and Coercivity $\left(\mathrm{H}_{\mathrm{c}}\right)$ were determined.

\section{RESULTS}

Figure 1 shows the Differential Thermal Analysis (DTA) plot ( $a$ and $b$ ) of the synthesized mixture of barium-iron oxalates precursors at two different $\mathrm{Fe}^{3+} / \mathrm{Ba}^{2+}$ mole ratios 12 and 8.57 respectively. It can be seen in peaks I-IV that an endothermic reaction occurred at around (95.11, 158.52, 182.45 and $232.15^{\circ} \mathrm{C}$ ) which corresponds to the dehydration of iron and barium oxalates. This is consistent with earlier findings suggesting that, two different crystals hydrate types namely $\mathrm{MeC}_{2} \mathrm{O}_{4} \cdot 2 \mathrm{H}_{2} \mathrm{O}$ and $\mathrm{MeC}_{2} \mathrm{O}_{4} \cdot 3 \mathrm{H}_{2} \mathrm{O}$ (Me = metal ion) (Shafi and Gedanken, 1999; Abe and Narita, 1997; Hessien, 2008). Thereafter, peaks V, VI and VII $\left(448.02,493.88\right.$ and $\left.586.56^{\circ} \mathrm{C}\right)$ were significantly related to the anhydrous oxalate mixture decomposition into both metal oxide and gases $\left(\mathrm{CO}_{2}\right.$ and $\mathrm{CO}$ ). Figure $1 \mathrm{~b}$ shows that the VI peak has higher intensity in the case of $\mathrm{Fe}^{3+} / \mathrm{Ba}^{2+}$ mole ratio 8.57 as compared with mole ratio 12 . This is most likely due to the increase of barium oxalate amount. Peak VIII in the plot at $\left(956.90^{\circ} \mathrm{C}\right)$, showed the initial step to form $\mathrm{BaFe}_{12} \mathrm{O}_{19}$, Moreover, the intensity and sharpness of peak VIII in (plot b) was also increased, indicating that the stability of the formed barium ferrite will be increased with increasing content of barium oxalate ratio. Therefore, the DTA results indicate that barium ferrite cannot form before $956.90^{\circ} \mathrm{C}$ (Carp et al., 1998). 


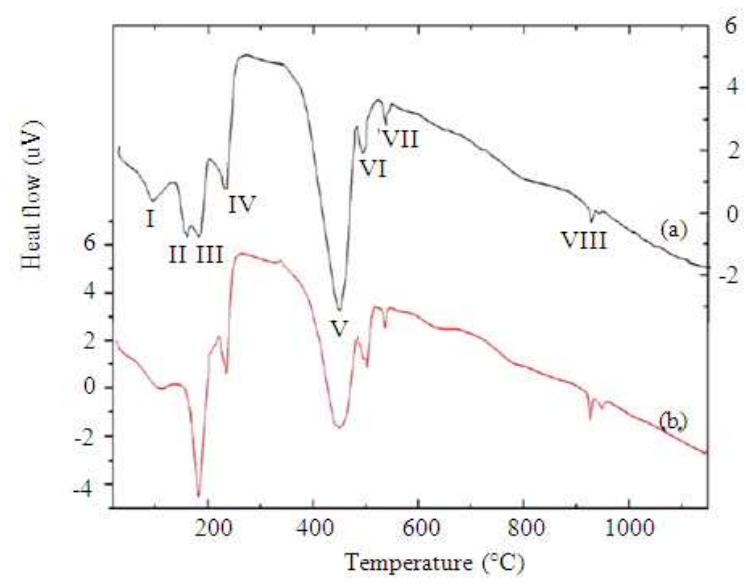

Fig. 1: Thermal profiles (DTA) of mixtures of bariumiron oxalates precursors at $\mathrm{Fe}^{3+} / \mathrm{Ba}^{2+}$ mole ratios (a) 12 and (b) 8.57

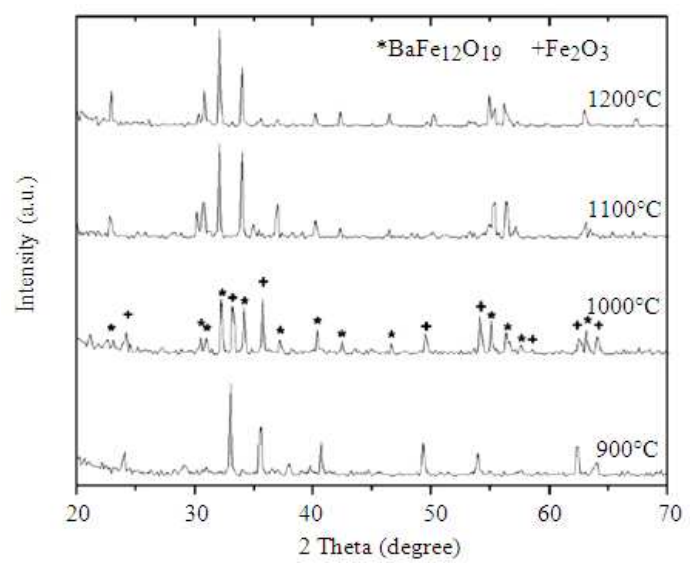

Fig. 2: XRD patterns of $\mathrm{BaFe}_{12} \mathrm{O}_{19}$ from barium-iron oxalate precursor with $\mathrm{Fe}^{3+} / \mathrm{Ba}^{2+}$ mole ratio 8.57 thermally treated at different temperatures (900$200^{\circ} \mathrm{C}$ ) for $2 \mathrm{~h}$

Figure 2 shows the XRD patterns of the calcined powder of $\mathrm{BaFe}_{12} \mathrm{O}_{19}$ obtained from barium-iron oxalate precursor solutions, with $\mathrm{Fe}^{3+} / \mathrm{Ba}^{2+}$ mole ratio 8.57 thermally treated at different temperatures (900$1200^{\circ} \mathrm{C}$ ) for $2 \mathrm{~h}$. On the start of the annealing process at $\left(900^{\circ} \mathrm{C}\right)$, a complete absence of M-type barium ferrite phase. Instead, the hematite $\mathrm{Fe}_{2} \mathrm{O}_{3}$ phase appears as a major phase, which is consistent with DTA results. But at $\left(1000^{\circ} \mathrm{C}\right)$ the concentration of the hematite phase decreases and barium ferrite phase was detected. Increasing the annealing temperature to $1100^{\circ} \mathrm{C}$, enhanced the formation of barium hexaferrite phase and decreased the hematite $\mathrm{Fe}_{2} \mathrm{O}_{3}$ phase. At the calcinations temperature $\left(1200^{\circ} \mathrm{C}\right)$, single phase of barium hexaferrite $\left(\mathrm{BaFe}_{12} \mathrm{O}_{19}\right)$ evidently was formed.

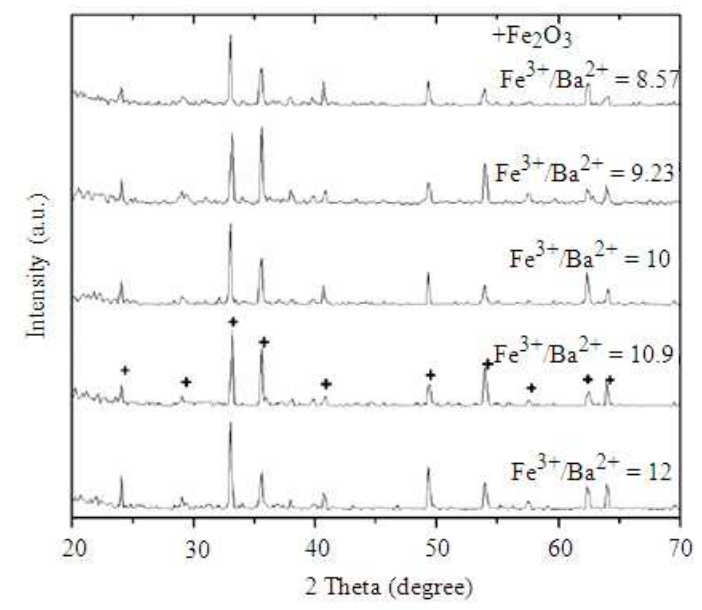

Fig. 3: XRD patterns of $\mathrm{BaFe}_{12} \mathrm{O}_{19}$ from barium-iron oxalate precursor with different $\mathrm{Fe}^{3+} / \mathrm{Ba}^{2+}$ mole ratio and thermally treated at $900^{\circ} \mathrm{C}$ for $2 \mathrm{~h}$

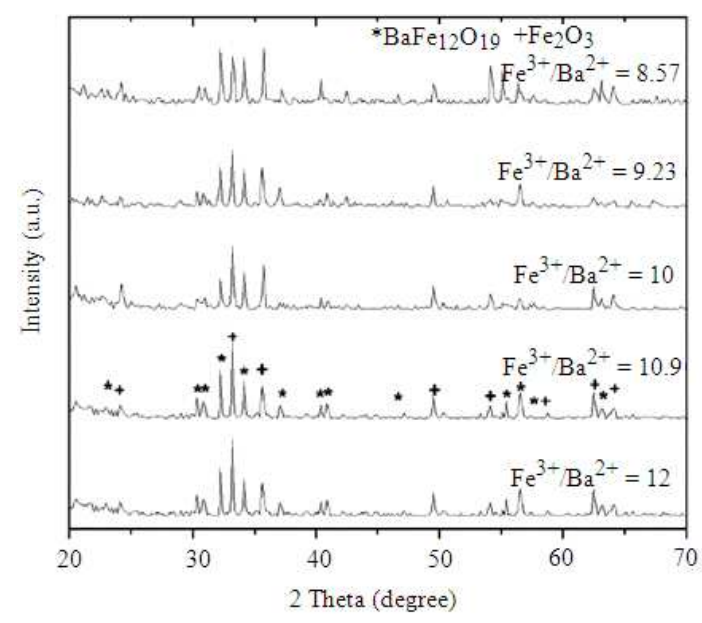

Fig. 4: XRD patterns of $\mathrm{BaFe}_{12} \mathrm{O}_{19}$ from barium-iron oxalate precursor with different $\mathrm{Fe}^{3+} / \mathrm{Ba}^{2+}$ mole ratio and thermally treated at $1000^{\circ} \mathrm{C}$ for $2 \mathrm{~h}$

XRD analysis was carried out in this study to investigate the effect of $\mathrm{Fe}^{3+} / \mathrm{Ba}^{2+}$ mole ratios of the powders thermally treated at different temperatures $\left(900-1200^{\circ} \mathrm{C}\right)$ for $2 \mathrm{~h}$ and the results are presented in Fig. 3-6. The results in Fig. 3 indicate that the thermal calcination of barium-iron oxalate precursor at $900^{\circ} \mathrm{C}$ has not yielded barium ferrite phase $\mathrm{BaFe}_{12} \mathrm{O}_{19}$ in any case. Instead iron oxide $\left(\mathrm{Fe}_{2} \mathrm{O}_{3}\right)$ phase has appeared clearly in all the $\mathrm{Fe}^{3+} / \mathrm{Ba}^{2+}$ ratio. These results confirm the DTA results, which showed no sign of $\mathrm{BaFe}_{12} \mathrm{O}_{19}$ formation at $900^{\circ} \mathrm{C}$. Figure 4 shows XRD patterns at annealing temperature $1000^{\circ} \mathrm{C}$, formation of barium ferrite was observed for all mole ratios. 


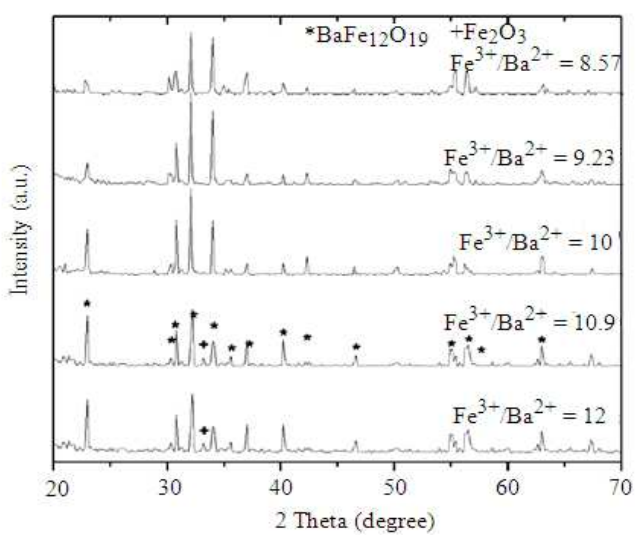

Fig. 5: XRD patterns of $\mathrm{BaFe}_{12} \mathrm{O}_{19}$ from barium-iron oxalate precursor with different $\mathrm{Fe}^{3+} / \mathrm{Ba}^{2+}$ mole ratio and thermally treated at $1100^{\circ} \mathrm{C}$ for $2 \mathrm{~h}$

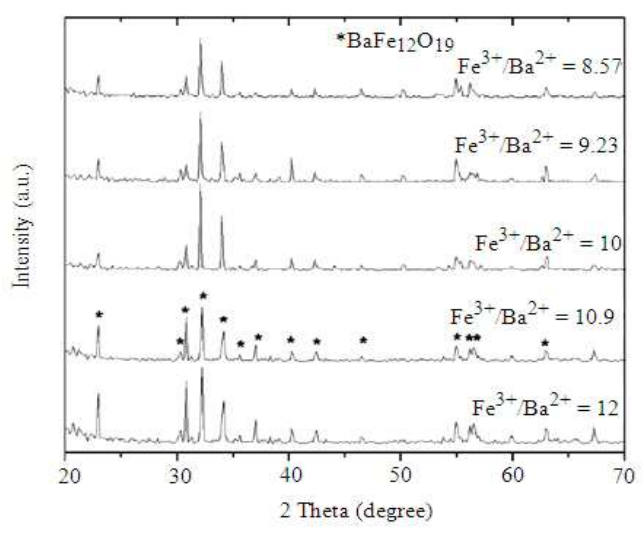

Fig. 6: XRD patterns of $\mathrm{BaFe}_{12} \mathrm{O}_{19}$ from barium-iron oxalate precursor with different $\mathrm{Fe}^{3+} / \mathrm{Ba}^{2+}$ mole ratio and thermally treated at $1200^{\circ} \mathrm{C}$ for $2 \mathrm{~h}$

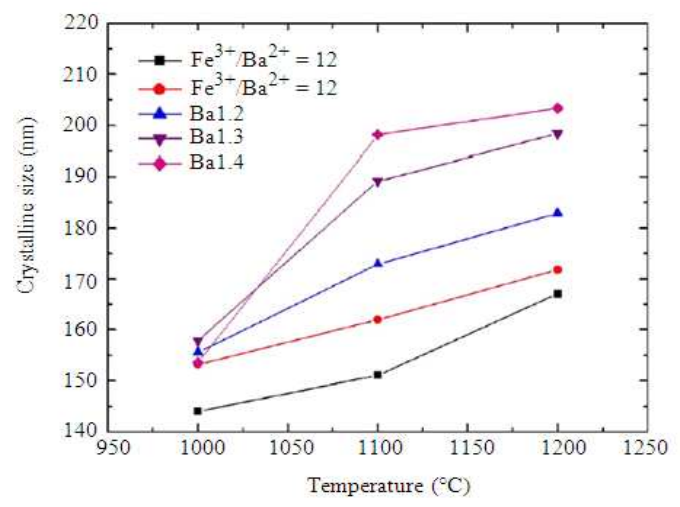

Fig 7: Effect of annealing temperature and mole ratio on the crystalline size of the prepared barium hexaferrite
As expected, increasing the $\mathrm{Fe}^{3+} / \mathrm{Ba}^{2+}$ mole ration enhanced the formation of barium ferrite phase (i.e., decreasing the amount of $\mathrm{Fe}_{2} \mathrm{O}_{3}$ ). Figure 5 showed the XRD patterns of $\mathrm{BaFe}_{12} \mathrm{O}_{19}$ precursor powders at $1100^{\circ} \mathrm{C}$. The formation of barium ferrite phase was highly enhanced for all mole ratios, while the $\mathrm{Fe}_{2} \mathrm{O}_{3}$ formation diminished significantly. It can be also observed that single phase of well crystalline $\mathrm{BaFe}_{12} \mathrm{O}_{19}$ was first obtained at $\mathrm{Fe}^{3+} / \mathrm{Ba}^{2+}$ mole ratio of 9.23 and 8.57 at annealing temperature $1100^{\circ} \mathrm{C}$. Raising the calcination temperature for the precursor up to $1200^{\circ} \mathrm{C}$ (Fig. 6), the single phase $\mathrm{BaFe}_{12} \mathrm{O}_{19}$ appeared at all different $\mathrm{Fe}^{3+} / \mathrm{Ba}^{2+}$ mole ratio. At the same time no sign of iron oxide $\left(\mathrm{Fe}_{2} \mathrm{O}_{3}\right)$ appeared. Figure 7 shows the effect of various mole ratios on the crystalline size of the obtained powders. It can be observed that increasing the annealing temperatures helps significantly agglomeration of the particles and grains growth during calcination course. This leads to the increase of grain size and formation of single phase barium hexaferrite powders.

Figure 8 displays SEM micrographs of $\mathrm{BaFe}_{12} \mathrm{O}_{19}$ powders obtained from oxalate precursors with $\mathrm{Fe}^{3+} / \mathrm{Ba}^{2+}$ mole ratio of 9.23 and annealed for $2 \mathrm{~h}$.

Clearly, it appears that increasing calcination temperature $\left(900-1200^{\circ} \mathrm{C}\right)$ has a substantial effect on the microstructure of synthesized $\mathrm{BaFe}_{12} \mathrm{O}_{19}$ powders.
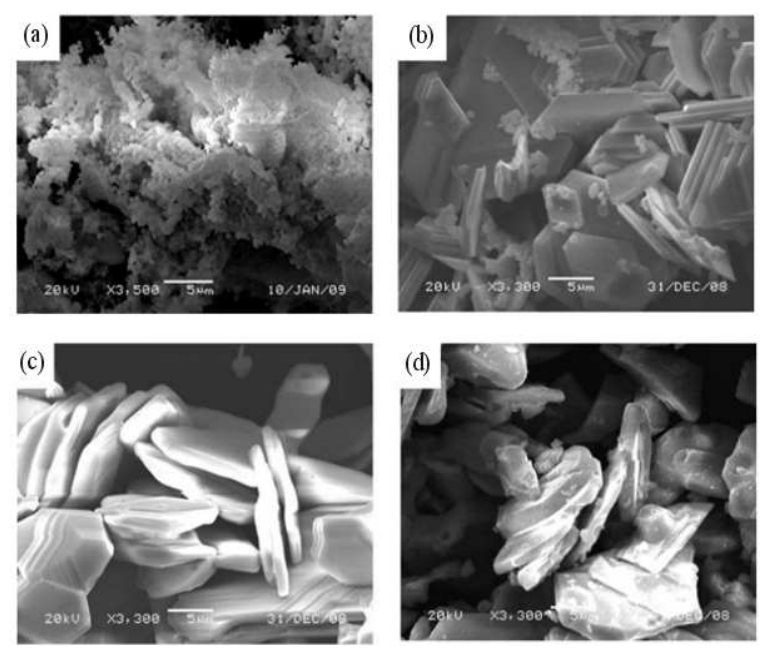

Fig. 8: Effect of annealing temperatures on the microstructure of synthesized $\mathrm{BaFe}_{12} \mathrm{O}_{19}$ powders obtained from oxalate precursors with $\mathrm{Fe}^{3+} / \mathrm{Ba}^{2+}$ mole ratios of 9.23 and annealed for 2 h. (a) $900^{\circ} \mathrm{C}$; (b) $1000^{\circ} \mathrm{C}$; (c) $1100^{\circ} \mathrm{C}$; (d) $1200^{\circ} \mathrm{C}$ 


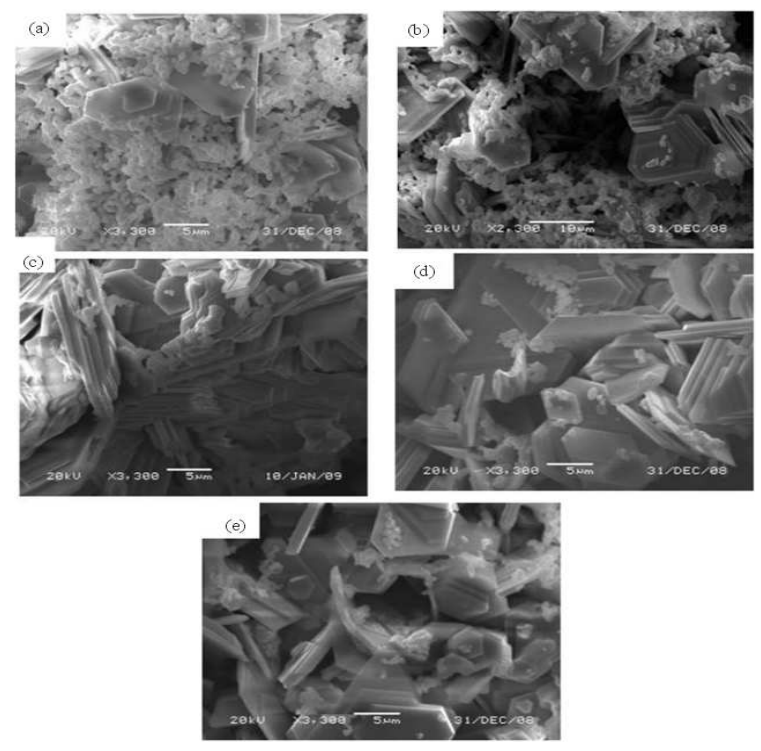

Fig. 9: Effect of $\mathrm{Fe}^{3+} / \mathrm{Ba}^{2+}$ mole ratios on the microstructure of synthesized $\mathrm{BaFe}_{12} \mathrm{O}_{19}$ powders obtained from oxalate precursors and annealed at $1000^{\circ} \mathrm{C}$ for $2 \mathrm{~h}$. (a) $\mathrm{Fe}^{3+} / \mathrm{Ba}^{2+}=12$; (b) $\mathrm{Fe}^{3+} / \mathrm{Ba}^{2+}=10.9$; (c) $\mathrm{Fe}^{3+} / \mathrm{Ba}^{2+}=10$; (d) $\mathrm{Fe}^{3+} / \mathrm{Ba}^{2+}=9.23$ and (e) $\mathrm{Fe}^{3+} / \mathrm{Ba}^{2+}=8.57$

In Fig. 8a, fine precipitated particles, with random grain orientation. This confirms the previous results of XRD and DTA, which showed no sign of $\mathrm{BaFe}_{12} \mathrm{O}_{19}$ growth at $900^{\circ} \mathrm{C}$. However, as the annealing temperatures increased to $1000^{\circ} \mathrm{C}$ Fig. $8 \mathrm{~b}$, individual particles possess a plate-like hexagonal shape containing a fewer numbers of spherical small particles. At annealing temperature $1100^{\circ} \mathrm{C}$ (Fig. 8c), the ferrite powders showed uniform coarse structure with a wellclear hexagonal shape which is in line with XRD patterns in Fig. 2, for where pure single crystal peaks of barium ferrite was very evident. The grains were then started to distort again at $1200^{\circ} \mathrm{C}$ (Fig. 8d), which may lead to agglomeration of the particles at more higher annealing temperatures.

Figure 9a-e presented the SEM micrographs of synthesized $\mathrm{BaFe}_{12} \mathrm{O}_{19}$ powders obtained from oxalate precursors and annealed at $1000^{\circ} \mathrm{C}$ for $2 \mathrm{~h}$. Effect of changing $\mathrm{Fe}^{3+} / \mathrm{Ba}^{2+}$ mole ratios on the microstructure was observed. In Fig. 9a and b, very fine particles of hematite powder started to agglomerate, where the mole ratios of $\mathrm{Fe}^{3+} / \mathrm{Ba}^{2+}$ were 12 and 10.9 respectively. In addition, a few large crystal particles were formed, indicating that these ratios of the composition were insufficient for the complete formation of the structure.

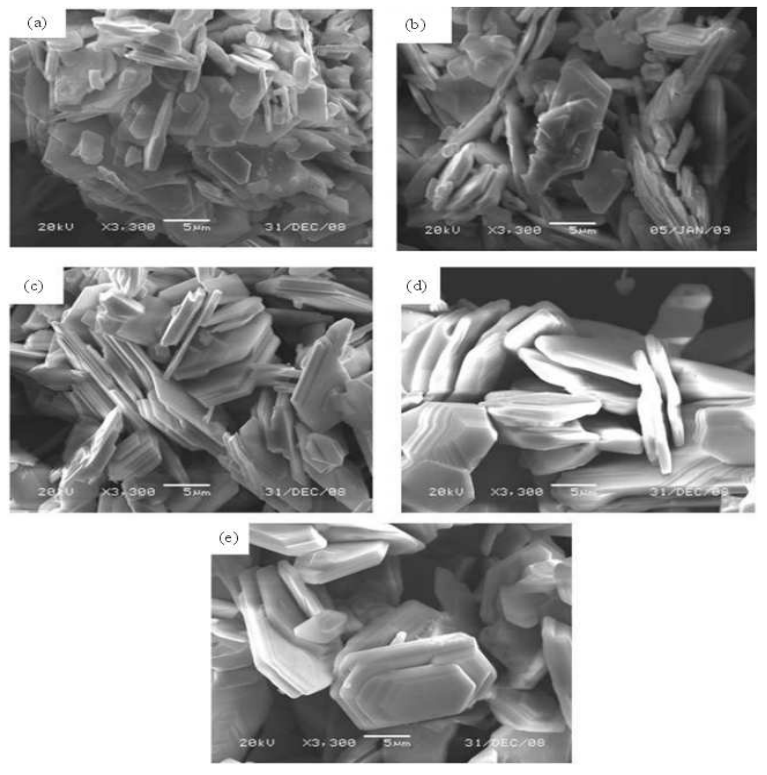

Fig. 10: Effect of $\mathrm{Fe}^{3+} / \mathrm{Ba}^{2+}$ mole ratios on the microstructure of synthesized $\mathrm{BaFe}_{12} \mathrm{O}_{19}$ powders obtained from oxalate precursors and annealed at $1100^{\circ} \mathrm{C}$ for $2 \mathrm{~h}$. (a) $\mathrm{Fe}^{3+} / \mathrm{Ba}^{2+}=12$; (b) $\mathrm{Fe}^{3+} / \mathrm{Ba}^{2+}=10.9$; (c) $\mathrm{Fe}^{3+} / \mathrm{Ba}^{2+}=10$; (d) $\mathrm{Fe}^{3+} / \mathrm{Ba}^{2+}=9.23$ and (e) $\mathrm{Fe}^{3+} / \mathrm{Ba}^{2+}=8.57$

As the $\mathrm{Ba}^{2+}$ ion concentration increased in the composition of the samples (Fig. 9c-e), uniform and coarse structure with clear homogeneous microstructure become more pronounced. Moreover, a well-clear crystalline micro-structure containing a fewer numbers of spherical small particles can be seen in these SEM micrographs. As the annealing temperature increased to $1100^{\circ} \mathrm{C}$ (Fig. 10a-e), the produced powders of $\mathrm{BaFe}_{12} \mathrm{O}_{19}$ possessed very well-defined plate-like hexagonal shape.

\section{DISCUSSION}

Table 1 and Fig. 11-14 present the magnetic properties of the synthesized barium ferrite powders, which were obtained at room temperature under an applied field of $10 \mathrm{kOe}$. The results showed that the saturation magnetization of the produced powders increased by increasing the temperatures. Figure 11 display the effect of annealing temperature on the hystersis loop of $\mathrm{BaFe}_{12} \mathrm{O}_{19}$ powders obtained from oxalate precursors at $\mathrm{Fe}^{3+} / \mathrm{Ba}^{2+}$ mole ratio 10 . This is likely due to the presence of single domain of $\mathrm{BaFe}_{12} \mathrm{O}_{19}$ particles. In line with SEM results, the change in magnetic properties can be attributed to the presence of well crystalline $\mathrm{BaFe}_{12} \mathrm{O}_{19}$ microstructures, as the annealing temperature of the powders was increasing gradually to reach optimum conditions. 
Am. J. Applied Sci., 7 (7): 914-921, 2010

Table 1: Effect of $\mathrm{Fe}^{3+} \mathrm{Ba}^{2+}$ mole ratios and annealing temperature on the magnetic properties of Barium hexaferrite

\begin{tabular}{lcccl}
\hline & \multicolumn{4}{c}{ Magnetic properties } \\
$\begin{array}{l}\mathrm{Fe}^{3+} / \mathrm{Ba}^{2+} \\
\text { mole ratio }\end{array}$ & Temp. $\left({ }^{\circ} \mathrm{C}\right)$ & $\mathrm{Ms}\left(\mathrm{emu} \mathrm{g}^{-1}\right)$ & $\mathrm{Mr}\left(\mathrm{emu} \mathrm{g}^{-1}\right)$ & $\mathrm{Hc}(\mathrm{Oe})$ \\
\hline 12 & 900 & 3.667 & 1.3710 & 666.0 \\
& 1000 & 33.010 & 3.2640 & 250.0 \\
& 1100 & 62.440 & 21.4100 & 662.6 \\
& 1200 & 66.360 & 17.5000 & 503.8 \\
10.91 & 900 & 2.074 & 0.8269 & 643.7 \\
& 1000 & 34.220 & 3.0660 & 235.4 \\
& 1100 & 67.150 & 21.0100 & 641.6 \\
& 1200 & 67.210 & 13.6900 & 387.5 \\
10 & 900 & 1.702 & 0.6210 & 653.0 \\
& 1000 & 37.400 & 5.5310 & 381.1 \\
& 1100 & 67.590 & 18.4500 & 556.6 \\
& 1200 & 70.250 & 16.6400 & 451.3 \\
9.23 & 900 & 1.733 & 0.6292 & 653.3 \\
& 1000 & 46.820 & 3.4710 & 172.6 \\
& 1100 & 65.440 & 20.8300 & 837.8 \\
8.57 & 1200 & 68.450 & 15.1100 & 480.6 \\
& 900 & 2.728 & 2.7280 & 808.7 \\
& 1000 & 44.800 & 3.5070 & 240.8 \\
& 1100 & 64.960 & 19.1200 & 620.8 \\
& 1200 & 67.230 & 18.7700 & 536.7 \\
\hline
\end{tabular}

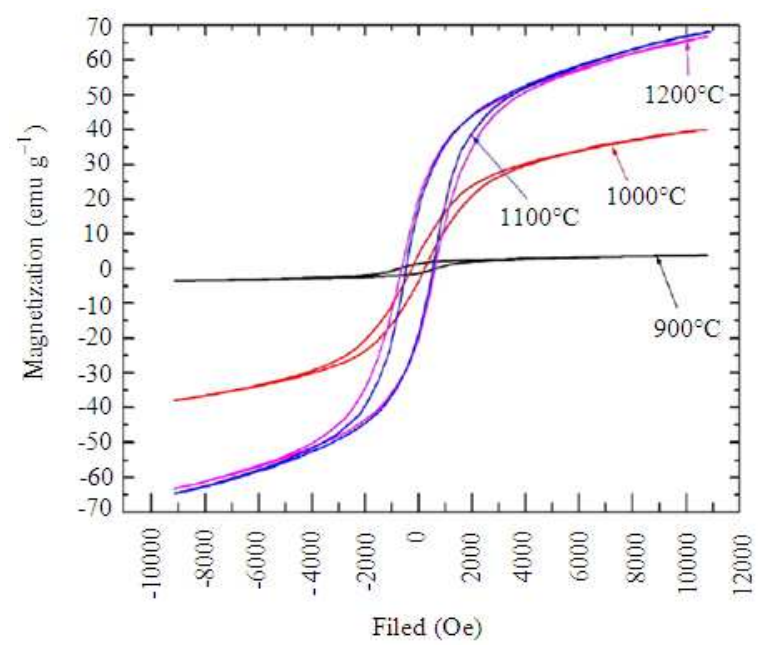

Fig. 11: Effect of annealing temperature on the M-H hysteresis loop of synthesized $\mathrm{BaFe}_{12} \mathrm{O}_{19}$ powders obtained from oxalate precursors at $\mathrm{Fe}^{3+} / \mathrm{Ba}^{2+}$ mole ratio 10

Figure 12-14 show the effect of $\mathrm{Fe}^{3+} / \mathrm{Ba}^{2+}$ mole ratio on the $\mathrm{M}-\mathrm{H}$ hysteresis loop of synthesized $\mathrm{BaFe}_{12} \mathrm{O}_{19}$ powders obtained from oxalate precursors and annealed for $2 \mathrm{~h}$ at 1000,1100 and $1200^{\circ} \mathrm{C}$, respectively. The maximum saturation magnetization value of 70.25 emu $\mathrm{g}^{-1}$ was obtained for the precursor prepared at $\mathrm{Fe}^{3+} / \mathrm{Ba}^{2+}$ mole ratio 10 at $1200^{\circ} \mathrm{C}$ for $2 \mathrm{~h}$. This results shows that saturation magnetization values obtained from the oxalate precursor method was quite close to the theoretical limit of $72 \mathrm{emu} \mathrm{g}^{-1}$ (Pillai et al., 1993).

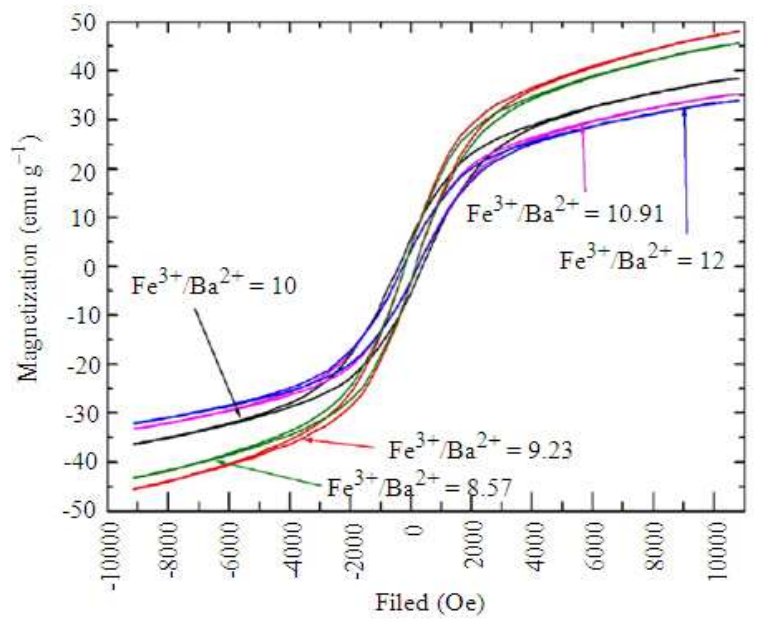

Fig. 12: Effect of $\mathrm{Fe}^{3+} / \mathrm{Ba}^{2+}$ mole ratio on the $\mathrm{M}-\mathrm{H}$ hysteresis loop of synthesized $\mathrm{BaFe}_{12} \mathrm{O}_{19}$ powders obtained from oxalate precursors and annealed at $1000^{\circ} \mathrm{C}$ for $2 \mathrm{~h}$

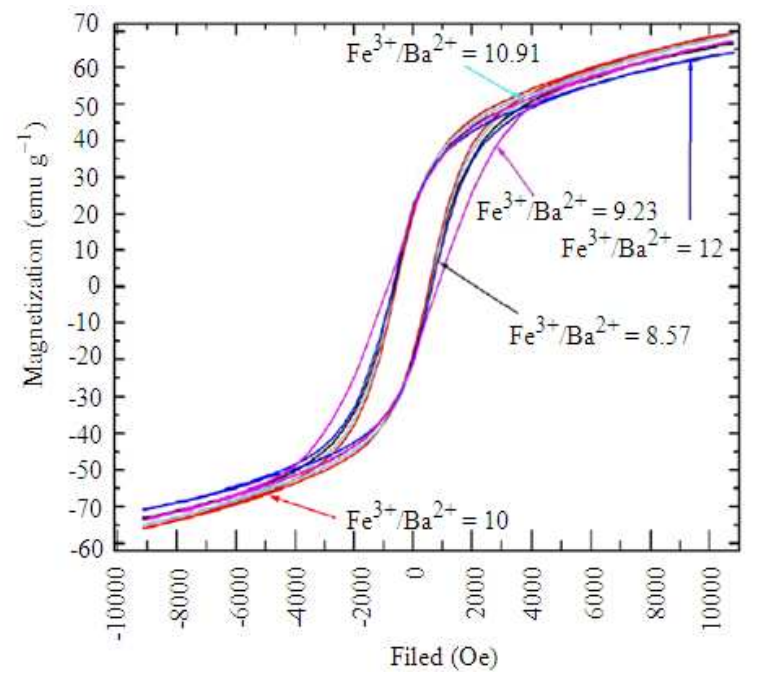

Fig. 13: Effect of $\mathrm{Fe}^{3+} / \mathrm{Ba}^{2+}$ mole ratio on the $\mathrm{M}-\mathrm{H}$ hysteresis loop of synthesized $\mathrm{BaFe}_{12} \mathrm{O}_{19}$ powders obtained from oxalate precursors and annealed at $1100^{\circ} \mathrm{C}$ for $2 \mathrm{~h}$

This was likely due to the presence of single domain of $\mathrm{BaFe}_{12} \mathrm{O}_{19}$ particles. Such high saturation magnetization for barium ferrite at a $1200^{\circ} \mathrm{C}$ can be attributed to the high-phase purity and well-defined crystalline structure of $\mathrm{BaFe}_{12} \mathrm{O}_{19}$. In contrast, the coercive force $\mathrm{Hc}$ results of $\mathrm{BaFe}_{12} \mathrm{O}_{19}$ powders, which is produced by the oxalate precursor method were lower than the theoretical value of (6700 Oe). In addition, these results might be related to the residual $\mathrm{Fe}_{2} \mathrm{O}_{3}$ having a high intrinsic coercive force (Hessien et al., 2008). 
Am. J. Applied Sci., 7 (7): 914-921, 2010

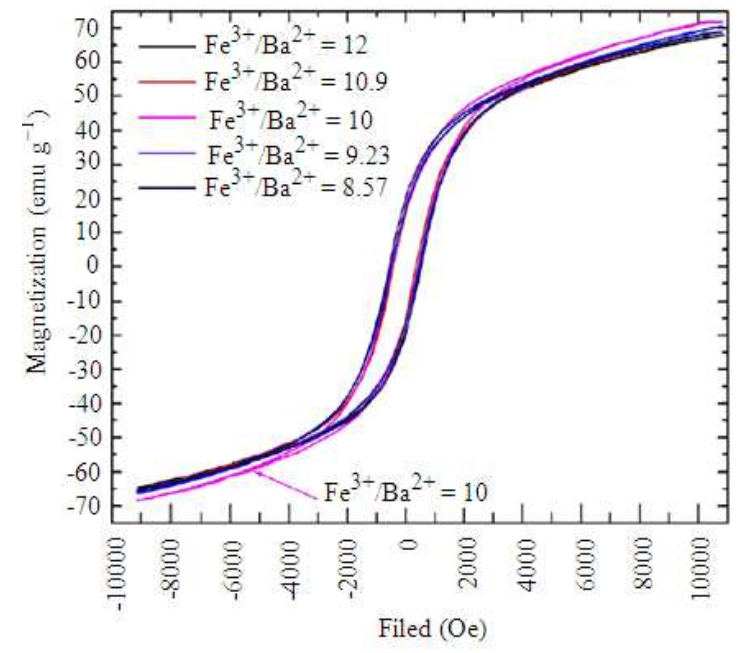

Fig. 14: Effect of $\mathrm{Fe}^{3+} / \mathrm{Ba}^{2+}$ mole ratio on the $\mathrm{M}-\mathrm{H}$ hysteresis loop of synthesized $\mathrm{BaFe}_{12} \mathrm{O}_{19}$ powders obtained from oxalate precursors and annealed at $1200^{\circ} \mathrm{C}$ for $2 \mathrm{~h}$

However, clearly this technique is a promise for providing $\mathrm{BaFe}_{12} \mathrm{O}_{19}$ with the highest saturation magnetization value. Figure 11-13 and Table 1, display effect of $\mathrm{Fe}^{3+} / \mathrm{Ba}^{2+}$ mole ratio on the $\mathrm{M}-\mathrm{H}$ hysteresis loop of synthesized $\mathrm{BaFe}_{12} \mathrm{O}_{19}$ powders obtained at different annealing temperatures.

Figure 12 showed that at annealing temperature $1000^{\circ} \mathrm{C}$ decreasing the $\mathrm{Fe}^{3+} / \mathrm{Ba}^{2+}$ mole ratios from $12-$ 8.57 increased the saturation magnetization of the formed $\mathrm{BaFe}_{12} \mathrm{O}_{19}$ particles from 33.01-44.8 emu g $\mathrm{g}^{-1}$. This is mainly due to increasing formation of well crystalline $\mathrm{BaFe}_{12} \mathrm{O}_{19}$ powders and decrease of the presence of non-magnetic species of $\mathrm{Fe}_{2} \mathrm{O}_{3}$ as the mole ratio percentage went up. These results are in substantial agreement with the previous XRD and SEM results, which was shown in Fig. 4 and 8. However, the effect of $\mathrm{Fe}^{3+} / \mathrm{Ba}^{2+}$ mole ratio on the M-H hysteresis loop of synthesized $\mathrm{BaFe}_{12} \mathrm{O}_{19}$ powders obtained at $1100^{\circ} \mathrm{C}$ and $1200^{\circ} \mathrm{C}$ was less significant in Fig. 13 and 14. This suggests that the $\mathrm{Fe}_{2} \mathrm{O}_{3}$ particles diminished dramatically at temperature $1100^{\circ} \mathrm{C}$ and $1200^{\circ} \mathrm{C}$, which lend support to the XRD and SEM results corresponding to these temperatures in Fig. 5 and 10, where the crystallinity of $\mathrm{BaFe}_{12} \mathrm{O}_{19}$ powders were very evident.

\section{CONCLUSION}

The structural and magnetic properties of newly prepared barium hexaferrite powders were studied in a comparative way. The results from DTA, XRD, SEM and VSM studies can be summarized as follows:
- Differential Thermal Analysis (DTA) plots of the synthesized mixture of barium-iron oxalates precursors showed that the initial step to form $\mathrm{BaFe}_{12} \mathrm{O}_{19}$ started at $\left(956.90^{\circ} \mathrm{C}\right)$

- Single phase of well crystalline $\mathrm{BaFe}_{12} \mathrm{O}_{19}$ was first obtained at $\mathrm{Fe}^{3+} / \mathrm{Ba}^{2+}$ mole ratio of 9.23 and 8.57 at annealing temperature $1100^{\circ} \mathrm{C}$ while at annealing temperature $1200^{\circ} \mathrm{C}$ the single phase $\mathrm{BaFe}_{12} \mathrm{O}_{19}$ appeared at all different $\mathrm{Fe}^{3+} / \mathrm{Ba}^{2+}$ mole ratio

- The morphology of the particles at 1000 and $1100^{\circ} \mathrm{C}$ are hexagonal platelet crystal. By increasing the temperature up to $1200^{\circ} \mathrm{C}$, grains have coalesced to form larger grains

- The oxalate precursor route has proven to produce pure barium ferrite powders with good magnetic properties with maximum saturation magnetization value of $\left(70.25 \mathrm{emu}^{-1}\right)$ and coercivity force (451.3 Oe)

- Regarding the particles size, it can be seen that, the minimum particle size appeared at $\left(1000^{\circ} \mathrm{C}\right)$ and the maximum size was found at $\left(1200^{\circ} \mathrm{C}\right)$, which most likely explained by the formation of the single phase of barium hexaferrite $\left(\mathrm{BaFe}_{12} \mathrm{O}_{19}\right)$

\section{REFERENCES}

Abe, O. and M. Narita, 1997. Mechanochemically assisted preparation process of barium hexaferrite powders. Solid State Ionics, 103: 101-103. DOI: 10.1016/S0167-2738(97)84016-7

Cabaoas, M.V. and J.M. Gonzalez-Calbet, 1993. Influence of the synthetic route on the $\mathrm{BaFe}_{12} \mathrm{O}_{19}$ properties. Solid State Ionics, 63-65: 207-212. DOI: 10.1016/0167-2738(93)90108-F

Carp, O., R. Barjega, E. Segal and M. Brezeanu, 1998. Nonconventional methods for obtaining hexaferrites: II. Barium hexaferrite. Thermochim. Acta, 318: 57-62. DOI: 10.1016/S00406031(98)00352-9

El-Hilo, M., H. Pfeiffer, K. O'Grady, W. Schuppel and E. Sinn et al., 1994. Magnetic properties of barium hexaferrite powders. J. Magn. Magn. Mater., 129: 339-347. DOI: 10.1016/0304-8853(94)90130-9

Garcia, R.M., E.R. Ruiz, E.E. Rams and R.M. Sanchez, 2001. Effect of precursor milling on magnetic and structural properties of $\mathrm{BaFe}_{12} \mathrm{O}_{19}$ M-ferrite. J. Magn. Magn. Mater., 223: 133-137. DOI: 10.1016/S0304-8853(00)00599-0

Hessien, M.M., 2008. Synthesis and characterization of lithium ferrite by oxalate precursor route. J. Mag. Magn. Mater., 320: 2800-2807. DOI: 10.1016/j.jmmm.2008.06.018 
Hessien, M.M., M.M. Rashad and K. El-Baraway, 2008. Controlling the composition and magnetic properties of strontium hexaferrite synthesized by co-precipitation method. J. Magn. Magn. Mater., 320: 336-343. DOI: 10.1016/j.jmmm.2007.06.009

Jacobo, S.E., L. Civale, C. Domingo-Pascual, R. Rodrigues-Clements and M.A. Blesa, 1997. Synthesis of ultrafine particles of barium ferrite by chemical coprecipitation. J. Mater. Sci., 32: 1025-1028. DOI: $10.1023 / \mathrm{A}: 1018582423406$

Kojimi, H. and E.P. Wohlfarth, 1982. Ferromagnetic Materials. North Holland, Amsterdam, pp: 305.

Liu, X., J. Wang, L.M. Gan and S.C. Ng, 1999. Improving the magnetic properties of hydrothermally synthesized barium ferrite. J. Magn. Magn. Mater., 195: 452-459. DOI: 10.1016/S0304-8853(99)00123-7

Matutes-Aquino, J., S. Dyaz-Castanon, M. MirabalGarcya and S.A. Palomares-Sanchez, 2000. Synthesis by coprecipitation and study of barium hexaferrite powders. Scripta Mater., 42: 295-299. DOI: 10.1016/S1359-6462(99)00350-4

Miller, J.S. and M. Drillon, 2002. Magnetism: Molecules to Materials III. Wiley-VCH Verlag GmbH, ISBN: 3527-30302-2, pp: 37.

Mishra, D., S. Anand, R.K. Panda and R.P. Das, 2004. studies on characterization, microstructures and magnetic properties of nano-size barium hexaferrite prepared through a hydrothermal precipitation-calcination route. Mater. Chem. Phys., $\quad$ 86: 132-136. DOI: 10.1016/j.matchemphys.2004.02.017

Ogasawara, T. and M.A.S. Oliveira, 2000. Microstructure and hysteresis curves of the barium hexaferrite from co-precipitation by organic agent J. Magn. Magn. Mater., 217: 147-154. DOI: 10.1016/S0304-8853(00)00080-9
Pillai, P., P. Kumar, M.S. Multani and D.O. Shah, 1993. Structure and magnetic properties of nanoparticles of barium ferrite synthesized using microemulsion processing. Colloids Surf. A: PhysiCochem. Eng. Aspects, 80: 69-75. DOI:10.1016/0927-7757(93)80225-4

Richerson, D.R., 1992. Modern Ceramic Engineering. 2nd Edn., Marcel Dekker. Inc., NY., ISBN: 08247-8634-3, pp: 294.

Sankaranarayanan, V.K. and D.C. Khan, 1996. Mechanism of the formation of nanoscale M-type barium hexaferrite in the citrate precursor method. J. Magn. Magn. Mater., 153: 337-346. doi:10.1016/0304-8853(95)00537-4

Shafi, K.V.P.M. and A. Gedanken, 1999. Sonochemical approach to the preparation of barium hexaferrite nanoparticles. Nanostruct. Mater., 12: 29-34. DOI: 10.1016/S0965-9773(99)00060-4

Smit, J. and H.P.J. Wijn, 1959. Ferrites: Physical Properties of Ferrimagnetic Oxides in Relation to their Technical Applications. NV Philips' Technical Library, Eindhoven, pp: 369.

Surig, C., K.A. Hempel and C. Sauer, 1996. Influence of stoichiometry on hexaferrite structure. J. Magn. Magn. Mater. $\quad$ 157-158: 268-269. DOI:10.1016/0304-8853(95)01201-X

Wang, M.L., Z. W. Shih and C.H. Lin, 1993. Reaction mechanism producing barium hexaferrites from goethite and barium hydroxide by hydrothermal method. J. Cryst. Growth, 130: 153-161. DOI: 10.1016/0022-0248(93)90847-P

Zhong, W., W. Ding, N. Zhang, J. Hong, Q. Yan and Y. Du, 1997. Key step in synthesis of ultrafine $\mathrm{BaFe}_{12} \mathrm{O}_{19}$ by sol-gel technique. J. Magn. Magn. Mater., 168: 196-202. DOI: 10.1016/S03048853(96)00664-6 